\title{
SOIL ENZYME ACTIVITIES UNDER LONG-TERM TILLAGE AND CROP ROTATION SYSTEMS IN SUBTROPICAL AGRO-ECOSYSTEMS
}

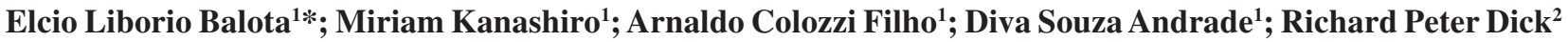 \\ ${ }^{1}$ Área de Solos, Instituto Agronômico do Paraná (IAPAR), Londrina, PR, Brasil; ${ }^{2}$ Crop \& Soil Science Department, Oregon State \\ University, Corvallis, OR, USA
}

Submited: December, 03, 2003; Returned to authors for corrections: August, 20, 2004; Approved: November, 09 , 2004

\section{SHORT COMMUNICATION}

\begin{abstract}
Agricultural practices that reduce soil degradation and improve agricultural sustainability are needed particularly for tropical/subtropical soils. No-tillage planting causes minimal soil disturbance and combined with crop rotation may hold potential to meet these goals. Soil enzyme activities can provide information on how soil management is affecting the potential to perform the processes in soils such as decomposition and nutrient cycling. Soil enzyme activities were investigated in a split-plot experiment ( 3 replications) where tillage (no till and conventional) was the main plot and crop rotation (soybean/wheat, S/W; maize/wheat, M/ W or cotton/wheat, C/W) was the subplot. The experiment was established in 1976 in southern Brazil. Soil samples were taken at 0-5, 5-10 and 10-20 cm depths in 1997 and 1998. The 0-5 cm layer under NT system showed increases up $68 \%$ for amylase, $90 \%$ for cellulase, $219 \%$ for arylsulfatase, $46 \%$ for acid phosphatase, and $61 \%$ for alkaline phosphatase. There were significant correlations of soil enzyme activities with total organic $\mathrm{C}$, and $\mathrm{C}$ and $\mathrm{N}$ microbial biomass. These results showed that NT increased microbial activity and that soil enzyme activity is a sensitive indicator of alteration soil quality by management.
\end{abstract}

Key words: enzyme activities; tillage systems; crop rotation; soil management; soil quality

\section{INTRODUCTION}

Soil management, which uses traditional plowing and disking to prepare the land may reduce soil organic matter (SOM) and microbial activity $(18,19,24)$. Consequently, agricultural practices toward smaller soil degradation is needed to improve soil quality and agricultural sustainability. No-tillage, planting with minimal soil disturbance combined with crop rotation protects the soil against degradation toward sustainability.

Tillage alters soil structure exposing more organic matter to microbial attack while no-tillage practices stimulate the formation and stabilization of macroaggregates, which represent an important mechanism for protection and maintenance of SOM (6) besides other effects as more stable temperature and changes in the distribution of organic matter and nutrients in the soil (18). The SOM decomposition is mediated by microorganisms, which have their activity stimulated on tropical soils where temperature is higher than temperate climate (8).

Crop rotations that have diverse crop sequences also can be important for maintaining and improve soil quality. Crop rotations change the soil habitat due to their difference in extract nutrients, depth of roots, amount of residue, which remain in soil and difference in their components. Crop rotations can stimulate soil biodiversity and biological activity over monoculturing. Soil management as no-tillage and crop rotations are important practices, which can reduce soil erosion, conserve organic matter and water and stimulate microbial activity $(18,19,24)$.

*Corresponding author. Mailing address: Área de Solos, Instituto Agronômico do Paraná, IAPAR, Caixa Postal 481, 86001-970, Londrina, Paraná, Brasil. E-mail: balota@iapar.br 
Soil enzymes are important for catalyzing innumerable reactions necessary for life processes of microorganisms in soils, decomposition of organic residues, cycling of nutrients, and formation of organic matter and soil structure (15). Although enzymes are primarily of microbial origin it can also be originate from plants and animals. These enzymes are constantly being synthesized, could be accumulated, inactivated and/or decomposed in the soil, assuming like this, great importance for the agriculture for their role in the recycling of the nutrients $(17,34)$.

Soil enzyme activities have successfully discriminated between a wide range of soil management practices $(17,24)$. It is known as well, that the excessive cultivation can cause decrease in the microbial biomass and its activity (24). Dick (18) showed that activities of some enzymes were higher in NT than CT in top $7.5 \mathrm{~cm}$ layer. Although there are a lot of information that show the relation between soil management and soil enzymes activities, very little is known about these effects under tropical/subtropical conditions $(11,14,18)$. In this context, the measurement of soil enzymes can be used as indicative of the biological activity or biochemical process. Soil enzyme activities have potential to provide a unique integrative biological assessment of soils because of their relationship to soil biology, easy of measurement, and rapid response to changes in soil management $(5,16,17)$.

The objectives of this study were determining the soil enzyme activities in soil under long-term crop rotations and tillage systems. We hypothesized that no-tillage and/or different crop rotation used would stimulate the enzyme activity.

\section{MATERIALS AND METHODS}

\section{Experimental site and soil samples}

A study of crop rotations and tillage established in 1976 was conducted at the Experimental Station of Agronomic Institute of Paraná (IAPAR), district of Londrina, State of Paraná,

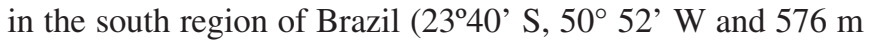
altitude). The soil is classified as Oxisol (Typic Haplorthox) with $85 \%$ of clay, $12 \%$ of silt, $3 \%$ of sand, $\mathrm{pH} 4.6$ and content of organic $\mathrm{C}$ and $\mathrm{P}$ according Table 1 . The experiment design was a split plot where tillage systems were the main plots (65 x $25 \mathrm{~m})$ and crop rotations (soybean/wheat, S/W; maize/wheat, M/W and cotton/wheat, $\mathrm{C} / \mathrm{W})$ were the subplots $(8 \times 25 \mathrm{~m}$ separated by $2.0 \mathrm{~m}$ ) with three replicates. No-tillage (NT) consists of planting crops in untilled soils by opening a narrow slot deep enough to cover the seed and conventional tillage (CT) consists of one deep discing and two light discings with a harrow for leveling the ground and preparing the seedbed. The fertilizers have been added according to the soil analysis done before each cropping. $\mathrm{N}$ fertilizer was never applied to the soybean crop. Five soil sub-samples were taken randomly from each subplot at 0-5, 5-10 and 10-20 cm depths in August 1997 and
Table 1. Total $\mathrm{C}$ and extractable $\mathrm{P}$ in soils under different tillage and crop rotations systems.

\begin{tabular}{|c|c|c|c|c|}
\hline \multirow{3}{*}{$\begin{array}{c}\text { Crop } \\
\text { Rotation }^{3}\end{array}$} & \multicolumn{2}{|c|}{ Total $\mathrm{C}^{1}$} & \multicolumn{2}{|c|}{ Extractable $\mathrm{P}^{2}$} \\
\hline & $\mathrm{CT}$ & NT & $\mathrm{CT}$ & NT \\
\hline & \multicolumn{2}{|c|}{$\mathrm{g} \mathrm{kg}^{-1}$} & \multicolumn{2}{|c|}{$\mathrm{mg} \mathrm{kg}^{-1}$} \\
\hline & \multicolumn{4}{|c|}{$0-5 \mathrm{~cm}$} \\
\hline S/W & 15.3 & 20.6 & 18.2 & 79.1 \\
\hline $\mathrm{M} / \mathrm{W}$ & 14.7 & 22.4 & 15.5 & 73.6 \\
\hline \multirow[t]{2}{*}{$\mathrm{C} / \mathrm{W}$} & 13.9 & 20.6 & 21.7 & 122.8 \\
\hline & \multicolumn{4}{|c|}{$5-10 \mathrm{~cm}$} \\
\hline S/W & 13.4 & 17.3 & 17.9 & 27.0 \\
\hline $\mathrm{M} / \mathrm{W}$ & 15.3 & 19.0 & 12.8 & 29.0 \\
\hline \multirow[t]{2}{*}{$\mathrm{C} / \mathrm{W}$} & 13.2 & 19.7 & 20.4 & 44.3 \\
\hline & \multicolumn{4}{|c|}{$10-20 \mathrm{~cm}$} \\
\hline S/W & 14.4 & 16.3 & 19.1 & 10.8 \\
\hline $\mathrm{M} / \mathrm{W}$ & 15.6 & 17.2 & 18.0 & 9.7 \\
\hline $\mathrm{C} / \mathrm{W}$ & 13.8 & 16.2 & 12.3 & 14.9 \\
\hline
\end{tabular}

${ }^{1}$ Carbon determination by Walkley \& Black; ${ }^{2}$ Extractable P by Mehlich; ${ }^{3}$ S: Soybean; W: Wheat; M: Maize; C: Cotton.

1998 (at the end of the winter crop). The samples were composted, homogenized and sieved through a $4 \mathrm{~mm}$ screen after removing any large plant material.

\section{Enzyme activities analysis}

Amylase (EC 3.2.1) and cellulase (EC 3.2.1.4) were determined according modified methodology of Pancholy and Rice (30) and Deng and Tabatabai (9). Arylsulfatase (arylsulfate sulfohydrolase, (EC 3.1.6.1) was determined by method of Tabatabai (34) and acid and alkaline phosphatase (EC 3.1.3) was determined by the method of Tabatabai (34) with a modified universal buffer (MUB) ( $\mathrm{pH} 6.5$ for acid phosphatase or $\mathrm{pH} 11.0$ for the alkaline phosphatase).

All determinations were made in triplicate and expressed on a dry weight basis. For amylase and cellulase activity results are expresses $\mu \mathrm{g}$ glucose (GLU) $\mathrm{g}^{-1} \mathrm{~d}^{-1}$. For activities of arylsulfatse and phosphatase results are expressed as $\mu \mathrm{g} p$ nitrophenol (PNP) $\mathrm{g}^{-1} \mathrm{~h}^{-1}$. Data were analyzed using the SAS statistical package (SAS Inst., 1998).

\section{RESULTS}

\section{Amylase activity}

Amylase activity (Table 2) varied from 350 to $730 \mu \mathrm{g} \mathrm{g}^{-1} \mathrm{~d}^{-1}$ in the CT plots and from 573 to $829 \mu \mathrm{g} \mathrm{g}^{-1} \mathrm{~d}^{-1}$ in the NT plots. NT resulted in a significant increase in amylase activity in all crops and depths with exception in maize at $5-10 \mathrm{~cm}$ depth where CT 
Table 2. Enzyme activities in soils under different tillage and crop rotations systems.

\begin{tabular}{|c|c|c|c|c|c|c|c|c|c|c|}
\hline \multirow{3}{*}{$\begin{array}{l}\text { Crop } \\
\text { Rotation }^{1}\end{array}$} & \multicolumn{2}{|c|}{ Amylase } & \multicolumn{2}{|c|}{ Cellulase } & \multicolumn{2}{|c|}{ Arylsulfatase } & \multicolumn{2}{|c|}{ Acid Phosphatase } & \multicolumn{2}{|c|}{ Alkaline Phosphatase } \\
\hline & $\mathrm{CT}$ & NT & $\mathrm{CT}$ & NT & $\mathrm{CT}$ & NT & $\mathrm{CT}$ & NT & $\mathrm{CT}$ & NT \\
\hline & \multicolumn{6}{|c|}{$\mathrm{mg} \mathrm{GLU} \mathrm{g}^{-1} \mathrm{~d}^{-1}$} & \multicolumn{3}{|c|}{$\operatorname{mg} P N P g^{-1} h^{-1}$} & \\
\hline & \multicolumn{10}{|c|}{$0-5 \mathrm{~cm}$} \\
\hline $\mathrm{S} / \mathrm{W}$ & $461 b^{2} A^{3}$ & $670 \mathrm{aA}$ & $118 \mathrm{aA}$ & $150 \mathrm{aA}$ & $8.9 \mathrm{bA}$ & $18.7 \mathrm{aB}$ & $621 \mathrm{bA}$ & $792 \mathrm{aA}$ & $147 \mathrm{bA}$ & $186 \mathrm{aA}$ \\
\hline $\mathrm{M} / \mathrm{W}$ & $451 \mathrm{bA}$ & $750 \mathrm{aA}$ & $94 \mathrm{bA}$ & $193 \mathrm{aA}$ & $8.4 \mathrm{bA}$ & $32.7 \mathrm{aA}$ & $572 \mathrm{bAB}$ & $832 \mathrm{aA}$ & $127 \mathrm{bA}$ & $207 \mathrm{aA}$ \\
\hline $\mathrm{C} / \mathrm{W}$ & $490 \mathrm{bA}$ & $929 \mathrm{aA}$ & $86 \mathrm{bA}$ & $220 \mathrm{aA}$ & $7.6 \mathrm{bA}$ & $28.0 \mathrm{aAB}$ & $508 \mathrm{bB}$ & $852 \mathrm{aA}$ & $86 \mathrm{bB}$ & $187 \mathrm{aA}$ \\
\hline & \multicolumn{10}{|c|}{$5-10 \mathrm{~cm}$} \\
\hline $\mathrm{S} / \mathrm{W}$ & 392 bB & $648 \mathrm{aA}$ & $67 \mathrm{aB}$ & $96 \mathrm{aA}$ & $8.0 \mathrm{bB}$ & $20.4 \mathrm{aA}$ & $482 \mathrm{bB}$ & $633 \mathrm{aA}$ & $103 \mathrm{bB}$ & $160 \mathrm{aA}$ \\
\hline $\mathrm{M} / \mathrm{W}$ & $730 \mathrm{aA}$ & $595 \mathrm{bA}$ & $139 \mathrm{aA}$ & $144 \mathrm{aA}$ & $12.5 \mathrm{bA}$ & $27.1 \mathrm{aA}$ & $608 \mathrm{aA}$ & $658 \mathrm{aA}$ & $133 \mathrm{aA}$ & $159 \mathrm{aA}$ \\
\hline $\mathrm{C} / \mathrm{W}$ & $350 \mathrm{bB}$ & $615 \mathrm{aA}$ & $87 \mathrm{aB}$ & $98 \mathrm{aA}$ & $4.1 \mathrm{bC}$ & $26.3 \mathrm{aA}$ & $495 \mathrm{bB}$ & $711 \mathrm{aA}$ & $75 \mathrm{bB}$ & $161 \mathrm{aA}$ \\
\hline & \multicolumn{10}{|c|}{$10-20 \mathrm{~cm}$} \\
\hline $\mathrm{S} / \mathrm{W}$ & $496 \mathrm{bAB}$ & $601 \mathrm{aA}$ & $92 \mathrm{aA}$ & $105 \mathrm{aA}$ & $6.1 \mathrm{bA}$ & $20.7 \mathrm{aB}$ & $615 \mathrm{aA}$ & $688 \mathrm{aA}$ & $134 \mathrm{aA}$ & $152 \mathrm{aA}$ \\
\hline $\mathrm{M} / \mathrm{W}$ & $546 \mathrm{bA}$ & $587 \mathrm{aA}$ & $105 \mathrm{aA}$ & $118 \mathrm{aA}$ & $6.7 \mathrm{bA}$ & $25.9 \mathrm{aA}$ & $625 \mathrm{bA}$ & $777 \mathrm{aA}$ & $142 \mathrm{bA}$ & $191 \mathrm{aA}$ \\
\hline $\mathrm{C} / \mathrm{W}$ & $446 \mathrm{bB}$ & $573 \mathrm{aA}$ & $82 \mathrm{aA}$ & $90 \mathrm{aA}$ & $4.2 \mathrm{bA}$ & $19.2 \mathrm{aB}$ & $458 \mathrm{bB}$ & $685 \mathrm{aA}$ & $100 \mathrm{aB}$ & $139 \mathrm{aA}$ \\
\hline
\end{tabular}

${ }^{1}$ S: Soybean; W: Wheat; M: Maize; C: Cotton; ${ }^{2}$ Values within a row of the same depth followed by same lower case letter comparing tillage are not significantly different at $\mathrm{P} \leq 0.05 ;{ }^{3}$ Values within a column of the same depth followed by same upper case letter comparing crop rotation are not significantly different at $\mathrm{P} \leq 0.05$.

resulted in values $23 \%$ higher than NT. NT increased amylase activity over CT from 45 to $69 \%$ in $0-5 \mathrm{~cm}$ depth, 65 to $76 \%$ in 5$10 \mathrm{~cm}$ depth and from 8 to $28 \%$ in $10-20 \mathrm{~cm}$ layer. Crop rotation influenced amylase activity at 5-10 and 10-20 cm depth under CT systems, and the M/W rotation was $20 \%$ higher than $\mathrm{S} / \mathrm{W}$, and $11 \%$ higher than $\mathrm{C} / \mathrm{W}$ rotation. In general amylase activity under NT was $37 \%$ higher than CT systems.

\section{Cellulase activity}

Cellulase activity (Table 2) varied from 67 to $139 \mu \mathrm{g} \mathrm{g}^{-1} \mathrm{~d}^{-1}$ in the CT plots and from 90 to $220 \mu \mathrm{g} \mathrm{g}^{-1} \mathrm{~d}^{-1}$ in the NT plots. NT resulted in a significantly increase in cellulase activity only at the first layer where maize and cotton showed higher cellulase activity than CT systems. Crop rotation influenced cellulase activity only at $5-10 \mathrm{~cm}$ under $\mathrm{CT}$ systems, where $\mathrm{M} / \mathrm{W}$ rotation showed higher activity than other rotations. In general cellulase activity under NT was $37 \%$ higher than CT systems while the $\mathrm{M} / \mathrm{W}$ rotation presented amylase activity $9 \%$ and $11 \%$ higher, respectively, than $\mathrm{S} / \mathrm{W}$ and $\mathrm{C} / \mathrm{W}$.

\section{Arylsulfatase activity}

Arylsulfatase activity (Table 2) varied from 4.11 to $12.52 \mu \mathrm{g}$ $\mathrm{g}^{-1} \mathrm{~h}^{-1}$ in the CT plots and from 19.17 to $32.65 \mu \mathrm{g} \mathrm{g}^{-1} \mathrm{~h}^{-1}$ in the NT plots. NT manage resulted in a significantly increase in arylsulfatase activity in all crop rotations at all depths. The increases over CT observed were from 110 to $288 \%$ at $0-5 \mathrm{~cm}$ depth, from 116 to $539 \%$ at $5-10 \mathrm{~cm}$ depth and from 240 to $353 \%$ at $10-20 \mathrm{~cm}$ depth. Crop rotation influenced arylsulfatase activity at 5-10 cm depth under CT while under NT systems there were effects of crop rotation at $0-5 \mathrm{~cm}$ and $10-20 \mathrm{~cm}$ depth. All of these effects were observed in $\mathrm{M} / \mathrm{W}$ rotation. In general arylsulfatase activity under NT was $215 \%$ higher than CT systems while the M/W rotation had $37 \%$ and $27 \%$ higher arylsulfatase activity than $\mathrm{S} / \mathrm{W}$ and $\mathrm{C} / \mathrm{W}$, respectively.

\section{Acid phosphatase activity}

Acid phosphatase activity (Table 2) varied from 458 to 625 $\mu \mathrm{g} \mathrm{g}^{-1} \mathrm{~h}^{-1}$ in the CT plots and from 633 to $852 \mu \mathrm{g} \mathrm{g}^{-1} \mathrm{~h}^{-1}$ in the NT plots. NT resulted in a significant increase in acid phosphatase activity in all crop rotations with exception in maize rotation at $5-10 \mathrm{~cm}$ and soybean at $10-20 \mathrm{~cm}$ depth. The increases in acid phosphatase activity due to soil management were from 28 to $68 \%$ at $0-5 \mathrm{~cm}$ depth, from 31 to $46 \%$ at $5-10 \mathrm{~cm}$ depth and from 12 to $50 \%$ at $10-20 \mathrm{~cm}$ depth. Crop rotation under CT influenced acid phosphatase activity at all depths, where $\mathrm{C} / \mathrm{W}$ had lower activity than other crop rotations. In general acid phosphatase activity under NT was $8 \%$ higher than $\mathrm{CT}$ systems while M/W had $6 \%$ and $10 \%$ higher activity than S/W and $\mathrm{C} / \mathrm{W}$, respectively.

\section{Alkaline phosphatase activity}

Alkaline phosphatase activity (Table 2) varied from 75 to $147 \mu \mathrm{g} \mathrm{g}^{-1} \mathrm{~h}^{-1}$ in the CT plots and from 139 to $207 \mu \mathrm{g} \mathrm{g}^{-1} \mathrm{~h}^{-1}$ in the NT plots. NT resulted in a significantly increase in alkaline 
phosphatase activity in all crops at $0-5 \mathrm{~cm}$, in S/W and C/W rotations at $5-10 \mathrm{~cm}$ and in $\mathrm{M} / \mathrm{W}$ at $10-20 \mathrm{~cm}$ depth. As observed for acid phosphatase the alkaline phosphatase activity also was influenced by crop rotation under $\mathrm{CT}$ at all depths. Alkaline phosphatase activity was lower in $\mathrm{C} / \mathrm{W}$ rotation than other crops, as observed in acid phosphatase. In general alkaline phosphatase activity under NT was $47 \%$ higher than CT systems while maize presented activity $10 \%$ and $28 \%$ higher, respectively, than soybean and cotton.

\section{DISCUSSION}

Amylase activities observed were similar to those (from 50 to $840 \mu \mathrm{g} \mathrm{g}^{-1}$ ) obtained under different vegetation types by Pancholy and Rice (30) while the cellulase activity were also similar those $95 \mu \mathrm{g} \mathrm{g}^{-1}$ under CT and $133 \mu \mathrm{g} \mathrm{g}^{-1}$ under NT (11). This trend of higher amylase activity under NT than CT, is related to total soil $\mathrm{C}$ content. Tillage only affected cellulase activity in the surface depth when NT had $90 \%$ greater activity than CT which corresponded to $45 \%$ greater total C. Amylase and cellulase did not decreased with soil depth and a decrease in organic $\mathrm{C}$ as observed previously by Deng and Tabatabai (11). These enzymes have an important role in residue decomposition. For example, cellulose is the most abundant compound in the biosphere, comprising almost half of the biomass synthesized by photosynthetic fixation of $\mathrm{CO}_{2}(20)$. So it is important to understand the factors that affect the degradation of cellulose in soils because the reactions involved provide readily available $\mathrm{C}$ for the growth of microorganisms (10).

Greater arylsulfatase activity (234\%) obtained in $0-20 \mathrm{~cm}$ under NT confirms a previous investigation that mulching and NT increase arylsulfatase activity significantly (12). However we did not observed decreased of arylsulfatase activity with increase of soil depth as observed previously by Deng and Tabatabai (12). Arylsulfatase is the enzyme that is involved in mineralization of ester sulfate in soils (34), and its activity has varied widely in the literature in relation to soil properties and management $(5,14,22,24)$. The greater arylsulfatase activity under NT may reflect the increase of fungal biomass because arylsulfatase has strong correlation with ergosterol (Taylor and Dick, unpublished), which is almost exclusively found in fungi (29). Furthermore, fungi have up to $42 \%$ of its $\mathrm{S}$ as ester sulfate, which is the substrate for arylsufatase, while bacteria has around $10 \%$ ester sulfate-S (32). This is consistent with Frey et al. (23) who found greater fungal than bacteria under reduced tillage. They observed that fungal hyphal length was 1.9 to 2.5 times higher in NT than CT. One of the reasons is that NT facilitates establishment and maintenance of hyphal compared to tillage that disrupts fungal networks.

The $46 \%$ increase of acid phosphatase and $61 \%$ increase of alkaline phosphatase activities due to NT in the surface layer show these enzymes are sensitive to disturbance. Phosphatases are a broad group of enzymes that hydrolyzes esters and anhydrides of phosphoric acid. Both acid and alkaline phosphatase activity varies widely due to soil management $(16,24)$, fertilizer (14), and tillage (27).

Our observation of higher soil enzyme activities under NT than CT is in agreement with other studies. For example Deng and Tabatabai (12) who observed higher values of arylsulfatase (30\%), acid phosphatase (17\%) and alkaline phosphatase (40\%) under NT than CT systems. However, unlike most other studies of NT where enzyme activities decrease below the top $5 \mathrm{~cm}$ our study showed activities remaining fairly constant down to 20 $\mathrm{cm}$. Most of the previous studies were in temperate regions, which have cold winter. Our study was in subtropical setting where soils remain warm year-around, which facilitates high rates of decomposition, reducing the potential to build up organic matter at the surface. This is reflected in total $\mathrm{C}$ levels which were only slightly higher in the $0-5 \mathrm{~cm}$ depth them lower depths in our study.

A fairly consistent effect of crop rotation was that M/W had significantly higher enzyme activities under CT compared to other crop rotations. This effect is likely due to the high biomass production of maize (about 9 tons $\mathrm{ha}^{-1} \mathrm{yr}^{-1}$ ). This would produce greater amounts of substrate for microbial growth and production of enzymes.

Soil management influences soil microorganisms and soil microbial processes through changes in the quantity and quality of plant residues entering the soil, and its spatial distribution. While in CT systems, organic matter is more thoroughly distributed than in NT systems where crop residues are concentrated on the soil surface. Mulching, generally, increases enzymes activities in soils. With the increasing of mulch there is an increased of the supply of the readily available substrate, such as carbohydrates, for microorganisms as well as soil enzymes. As a consequence, can occur an increase in glycosidase activities because these enzymes play a major role in degradation of carbohydrates in soils and the hydrolysis of these enzymes are believed to be important energy sources for the growth of soil microorganisms (11). Glycosidases are likely involved in C cycling by catalyzing decomposition and releasing energy source such as glucose (11).

Our results on a subtropical soil that NT increases the microbial biomass and enzyme activities are consistent with previous studies in temperate regions $(11,12,27)$. The high concentration of residue and roots of previous crops in the surface soil under NT can affect its microbial activity. One of those benefits effects due to NT may be by "rhizosphere effect", which probably contribute significant for higher enzyme activities when compared with CT systems (5). Rhizosphere is a zone where there is an increase in microbial and enzyme activity (7). Some enzyme activities (amylase, cellulase and invertase) can be more influenced by type of organic matter than the 
quantity of organic matter (30), once had been observed that mineralization of plant residue added to soil is controlled by $\mathrm{C}: \mathrm{N}$ ratio, and lignina, polyphenol and silica content (35). These crop rotation effects can be also due to different exudate and organic components from root systems and crop residues, which influence microbial activity differently.

In general has been accepted that there are a decrease in microbial activity with the increase of cultivation. As observed by Gupta and Germida (24) who found lower enzyme activities in all aggregates size fractions under cultivated soils than native soils. As enzymes play an important role in the biochemical mineralization of nutrients, these decreases in enzyme activities under CT might explain the lower microbial biomass and activities observed in the same experimental site $(2,3,4)$.

Simple correlation across all treatments and depths (Table 3) showed that soil enzyme activities were significantly correlated with $\mathrm{C}$ microbial biomass. This indicates that enzyme activities were associated with active microorganisms in soil which are the major source of soil enzymes. While the significant correlation between enzyme activities and organic $\mathrm{C}$ is likely due to higher $\mathrm{C}$ levels supporting greater microbial biomass that is more activity. Furthermore, higher organic matter provides a better environmental for stabilizing and protecting extra cellular enzymes. The activities of all five enzymes were significantly intercorrelated which suggest that tillage and crop rotations systems have similar effects on the activities of those enzymes involved in $\mathrm{C}, \mathrm{N}, \mathrm{P}$ and $\mathrm{S}$ cycling in soils (12).

We found no significant correlation between enzyme activities and soil pH. Similar observations also have been found $(1,20,21)$ even though phosphatases have been often closely correlated with soil $\mathrm{pH}(12,14,21,26)$. This because acid phosphatase predominanes in acid soils and alkaline phosphatase predominanes in alkaline soils (26). However, in our study this lack of correlation with $\mathrm{pH}$ may be due to the narrow range at $\mathrm{pHs}$ 4.1 and 4.7 .

There was no correlation between acid and alkaline phosphatase activities with extractable $\mathrm{P}$, which is consistent with other studies $(1,20)$. This lack of correlation between phosphatases and extractable P may be due to the suppression of soil phosphatase activity from long-term application of phosphate fertilizer (about $125 \mathrm{~kg} \mathrm{P}_{2} \mathrm{O}_{5}$ per ha per year) as suggested by Haynes and Williams (25). Thus, it seems phosphatases are stimulated when phosphate levels are low in soils (33).

Although the ecological significance of specific soil enzymes activities is still debatable (28) there are several works which show, in a clear way, the effects of soil management in enzyme activities $(5,11,12,14,16,24,27)$. The increase in soil enzyme activities may be the result of soil physical and chemical changes, so there is a direct expression on microbial biomass and soil enzyme activities. One argument, which can explain the increase in soil enzyme activities due to tillage, is that NT can improve the microbial habitat. Long-term tillage alters soil structure and can increase the losses of organic matter, because of tillage disrupt soil aggregates exposing 
more organic matter to microbial attack (6). The formation and stabilization of macroaggregates under NT soil represent an important mechanism for the protection and maintenance of soil organic matter that be lost under CT practices (6). Thus, macroaggregates provide an important microhabitat for microbial activity (13). Higher organic matter levels support greater microbial activity because of greater supplies of energy and nutrients. Additionally, greater humic content could facilities incorporation of soils enzymes into the soil matrix allowing stabilization of higher exoenzymes in soils because humic compounds are important in soil enzyme complexation $(16,31)$.

\section{ACKNOWLEDGEMENTS}

To CNPq - Conselho Nacional de Desenvolvimento Científico e Tecnológico (Brazilian National Research Council), for PostDoctorate fellowship to E. L. Balota, process 200440/00-4.

\section{RESUMO}

\section{Atividade enzimática em solo sob plantio direto e rotações de culturas em agro-ecossistema subtropical}

Práticas agrícolas que reduzam a degradação do solo e promovam sustentabilidade são importantes para os agrossistemas tropicais/subtropicais. O plantio direto (PD) diminui as perdas de solo e, se combinado com rotação de culturas pode proteger o solo da degradação físico-química provocada pela agricultura intensiva. A atividade enzimática do solo pode fornecer importantes informações de como o manejo do solo está afetando a decomposição da material orgânica e a ciclagem dos nutrientes. Assim, avaliou-se a atividade das enzimas amilase, celulose, arilsulfatase, fosfatase ácida e fosfatase alcalina em um experimento a campo, instalado em 1976 em Londrina, PR, que tem como tratamentos o preparo do solo (plantio direto ou convencional) nas parcelas e a rotação de culturas (soja/trigo, milho/trigo e algodão/trigo) nas subparcelas. Amostras de solos foram coletadas a 0-5, 5-10 e 10-20 cm de profundidade em 1997 e 1998. Na profundidade de 0-5 cm sob PD, observaram-se aumentos de $68 \%$ na atividade da amilase, $90 \%$ na celulase, $219 \%$ na arilsulfatase, $46 \%$ na fosfatase ácida e $61 \%$ na fosfatase alcalina. Observaram-se correlações significativas entre a atividade enzimática e o Corgânico total do solo e o $\mathrm{C}$ e $\mathrm{N}$ da biomassa microbiana. Esses resultados evidenciam que a atividade enzimática do solo é um indicador sensível de alterações na qualidade do solo, promovidas pelo manejo.

Palavras-chave: atividade enzimática, plantio direto, rotação de cultura, manejo do solo; qualidade do solo

\section{REFERENCES}

1. Baligar, V.C.; Wright, R.J.; Fageria, N.K.; Pitta, G.V.E. Enzyme activities in cerrado soils of Brazil. Commun. Soil Sci. Plant Anal., 30:1551-1560, 1999.

2. Balota, E.L.; Colozzi Filho, A.; Andrade, D.S.; Dick, R.P. Long-term tillage and crop rotation effects on microbial biomass and $\mathrm{C}$ and $\mathrm{N}$ mineralization in a Brazilian Oxisol. Soil Till. Res., 77:137-145, 2004.

3. Balota, E.L.; Colozzi-Filho, A.; Andrade, D.S.; Dick, R.P. Microbial biomass in soils under different tillage and crop rotation systems. Biol. Fertil. Soils., 38:15-20, 2003.

4. Balota, E.L.; Colozzi-Filho, A.; Andrade, D.S.; Hungria, M. Biomassa microbiana e sua atividade em solos sob diferentes sistemas de preparo e sucessão de culturas. R. Bras. Ci. Solo., 22:641-649, 1998.

5. Bandick, A.K.; Dick, R.P. Field management effects on soil enzyme activities. Soil Biol. Biochem., 31:1471-1479, 1999.

6. Beare, M.H.; Cabrera, M.L.; Hendrix, P.F.; Coleman, D.C. Aggregateprotected and unprotected organic matter pools in conventional and no-tillage soils. Soil Sci. Soc. Am. J., 58:787-795, 1994.

7. Bopaiah, B.M.; Shetty, H.S. Soil microflora and biological activities in the rhizospheres and root regions of coconut-based multistoreyed cropping and coconut monocropping systems. Soil Biol. Biochem., 23:89-94, 1991.

8. Coleman, D.; Oades, J.M.; Uehara, G. Soil organic matter: tropical vs. temperate. In: Coleman, D.; Oades, J.M.; Uehara, G. (eds.) Dynamics of soil organic matter in tropical ecosystem. University Hawaii Press, 1989, Niftal, 1-4.

9. Deng, S.P.; Tabatabai, M.A. Cellulase activity of soils. Soil Biol. Biochem., 26:1347-1354, 1994a.

10. Deng, S.P.; Tabatabai, M.A. Colorimetric determination of reducing sugars in soils. Soil Biol. Biochem., 26:473-477, 1994b.

11. Deng, S.P.; Tabatabai, M.A. Effect of tillage and residue management on enzyme activities in soils: II. Glycosidases. Biol. Fertil. Soils., 22:208-213, 1996.

12. Deng, S.P.; Tabatabai, M.A. Effect of tillage and residue management on enzyme activities in soils: III. Phosphatases and arylsulfatase. Biol. Fertil. Soils., 24:141-146, 1997.

13. Dick, R.P. A review: long-term effects of agricultural systems on soil biochemical and microbial parameters. Agric. Ecosystems Environ., 4:25-36, 1992.

14. Dick, R.P.; Rasmussen, P.E.; Kerle, E.A. Influence of long-term residue management on soil enzyme activities in relation to soil chemical properties of a wheat-fallow system. Biol. Fertil. Soils., 6:159-164, 1988 .

15. Dick, R.P.; Sandor, J.A.; Eash, N.S. Soil enzyme activities after 1500 years of terrace agriculture in the Colca Valley, Peru. Agric. Ecosystems Environ., 50:123-131, 1994

16. Dick, R.P. Soil enzyme activities as indicators of soil quality. In: Doran, J.W.; Coleman, D.C.; Bezdicek, D.F.; Stewart, B.A. (eds.) Defining soil quality for a sustainable environment. Soil Science Society of America, Madison, 1994, p.107-124.

17. Dick, R.P. Soil enzyme activities as integrative indicators of soil health. In: Pankhurst, C.E.; Doube, B.M.; Gupta, V.V.S.R. (eds.) Biological Indicators of Soil Health. CAB International, 1997, p. $121-156$.

18. Dick, W.A. Influence of long-term tillage and crop rotation combinations on soil enzyme activities. Soil Sci. Soc. Am. J., 48:569574, 1984.

19. Doran, J.W. Soil microbial and biochemical changes associated with reduced tillage. Soil Sci. Soc. Am. J., 44:765-771, 1980.

20. Eriksson, K.E.L.; Blanchette, R.A.; Ander, P. Biodegradation of cellulose. In: Eriksson, et al. (eds.) Microbial and Enzymatic Degradation of Wood and Wood Components. Springer-Verlag, New York, 1990, p.89-180. 
21. Fernandes, M.F.; Anjos, J.L.; Sobral, L.F.; Fernandes, R.P.M.; Araúlo, A.A. Efeito da saturação por bases sobre a atividade de fosfatases em um solo de tabuleiro costeiro cultivado com citros. I. Correlações entre a atividade enzimática e as diferentes características do solo alteradas pela calagem. R. Bras. Ci. Solo., 22:395-401, 1998.

22. Frankenberger, W.T.; Dick, W.A. Relationships between enzyme activities and microbial growth and activity indices in soil. Soil Sci. Soc. Am. J., 47:945-951, 1983.

23. Frey, S.D.; Elliott, E.T.; Paustian, K. Bacterial and fungal abundance and biomass in conventional and no-tillage agroecosystems along two climatic gradients. Soil Biol. Biochem., 31:573-585, 1999.

24. Gupta, V.V.S.R.; Germida, J.J. Distribution of microbial biomass and its activity in different soil aggregate size classes as affected by cultivation. Soil Biol. Biochem., 20:777-786, 1988.

25. Haynes, R.J.; Williams, P.H. Long-term effect of superphosphate on accumulation of soil phosphorus and exchangeable cations on a grazed, irrigated pasture site. Plant Soil., 142:123-133, 1992.

26. Juma, N.G.; Tabatabai, M.A. Distribution of phosphomonoesterases in soils. Soil Science., 126:101-108, 1978.

27. Kandeler, E.; Tscherko, D.; Spiegel, H. Long-term monitoring of microbial biomass, $\mathrm{N}$ mineralisation and enzyme activities of a Chernozem under different tillage management. Biol. Fertil. Soils., 28:343-351, 1999.

28. Nannipieri, P.; Grecco, S.; Ceccanti, B. Ecological significance of the biological activity in soil. In: Bollag, J.M.; Stozky, G. (eds.). Soil Biochemistry, vol 6. Marcel Dekker, New York, 1990, p.293-355.

29. Newell, S.Y.; Miller, J.D.; Fallon, R.D. Ergosterol content of salt marsh fungi: effect of growth conditions and mycelial age. Mycologia, 79:688-695, 1987

30. Pancholy, S.K.; Rice, E.L. Soils enzymes in relation to old field succession: amylase, cellulase, invertase, dehydrogenase, and urease. Soil Sci. Soc. Am. J., 37:47-50, 1973.

31. Paul, E.A.; McLaren, A.D. Biochemistry of soil subsystem. In: Paul, E.A.; McLaren, A.D. (eds.) Soil Biochemistry, vol. 3. Marcel Dekker, New York, 1975.

32. Saggar, S.; Bettany, J.R.; Stewart, W.B. Measurement of microbial sulfur in soil. Soil Biol. Biochem., 13:493-498, 1981.

33. Spiers, G.A.; McGill, W.B. Effects of phosphorus addition and energy supply on acid phosphatase activity in soils. Soil Biol. Biochem., $11: 3-8,1978$

34. Tabatabai, M.A. Enzymes. In: Weaver, R.W.; Augle, S.; Bottomly, P.J.; Bezdicek, D.; Smith, S.; Tabatabai, A.; Wollum, A. (eds.), Methods of soil analysis. Part 2. Microbial and biochemical properties, No. 5. Soil Science Society of America, Madison, 1994, p.775-833.

35. Tian, G.; Kang, B.T.; Brussaard, L. Biological effects of plant residues with contrasting chemical compositions under humid tropical conditions - decomposition and nutrient release. Soil Biol. Biochem., 24:1051-1060, 1992 